\title{
Oribatid mites (Acari, Oribatida) of various habitats in southern Andalusia (Spain)
}

\author{
STANISŁAW SENICZAK and ANNA SENICZAK \\ Department of Ecology, University of Technology and Life Sciences, Kordeckiego 20, \\ 85-225 Bydgoszcz, Poland \\ Corresponding author: Stanisław Seniczak, stseni@utp.edu.p1
}

(Received on 3 January 2008; Accepted on 24 April 2010)

\begin{abstract}
Oribatid mites were investigated in some habitats (litter under cypress, pine and larch trees, and patches of grasses, mosses and lichens) in southern Andalusia (Spain) in August 2005. The studied communities of oribatid mites were rather poor in terms of abundance and species diversity. The density of mites in cypress litter from the mountains (Granada, Ronda) was distinctly higher than in the coastal area (Benalmádena), which was probably caused by climatic conditions. The Oribatida achieved the highest density in grassy patches in Granada, but most species occurred in cypress litter from Ronda. Among oribatid species, Oribatula frisiae reached the highest density; also O. tibialis and Haplochthonius simplex were relatively abundant. Some species of Oribatida were rich in juveniles, but the age structure of species greatly depended on the kind of litter.
\end{abstract}

Keywords: South Andalusia, habitats, oribatid mites, population, community, juveniles, needle litter

\section{INTRODUCTION}

The order Oribatida comprises more than 9000 named species (SuBÍAs 2004; Norton \& Behan-Pelletier 2009), representing 172 families, most of which live in the soil. They are one of the most numerically dominant groups of arthropods in the upper soil horizons, where they feed on dead organic matter, fungi, algae, lichens, pollen or bacteria, playing an important role in terrestrial ecosystems. However, hot and dry summers in the Mediterranean region greatly limit the density and species number of these mites (Stamou \& Sgardelis 1989; Seniczak \& Seniczak 2006; SENICZAK et al. 2009).

The aim of this paper is to compare the communities of oribatid mites from various soil habitats (litter under cypress, pine, and larch trees, and patches of grasses, mosses and lichens) in the mountains and coastal areas of southern Andalusia. 


\section{STUDY AREA}

Andalusia is located in southeastern Spain, and includes Baetic mountains (Cordilleras Béticas), which decline in the south to the Mediterranean Sea. The costal part of Andalusia has a typical Mediterranean climate (summer temperature about $30^{\circ} \mathrm{C}$, winter temperature about $18^{\circ} \mathrm{C}$ ), with about 320 sunny days and yearly precipitation about $250 \mathrm{~mm}$, but the inland climate depends on altitude above the sea level. For example, in Granada city (about $680 \mathrm{~m}$ a.s.1.), the yearly mean temperature is $16.6^{\circ} \mathrm{C}$, and mean precipitation is $473 \mathrm{~mm}$, while in Ronda city (about $740 \mathrm{~m}$ a.s.1.) the temperature is lower $\left(15^{\circ} \mathrm{C}\right)$ and precipitation is higher $(607 \mathrm{~mm})$.

Plant cover of southern Andalusia varies due to topography. The lower parts of mountains are covered with large plantations of olive trees (Olea europea L.) and pastures, often with enclaves of trees and bushes: usually oaks (Quercus ilex L., $Q$. suber L.) and pines (Pinus halepensis Mill., P. pinaster Aiton.). The vegetation of river valleys includes ash trees (Fraxinus excelsior L.), willows (Salix spp.), poplars (Populus spp.), junipers (Juniperus communis L.), and aromatic and heather plants. In the coastal parts there are many touristic towns and villages, with planted bitter orange (Citrus aurantium L.), lemon [Citrus limon (L.) Burm. f.], cypress (Cupressus sp.), fig (Ficus carica L.), and jacaranda (Jacaranda sp.) trees.

\section{MATERIAL AND METHODS}

Samples of $500 \mathrm{~cm}^{3}$ each were taken on 15-21 August 2005, in 3 replicates, from the following areas:

- mountain areas [Granada - litter under cypress (Cupressus sp.) and pine trees (Pinus sp.), as well as patches of mosses and lichens or grasses; Ronda - litter under cypress, pine, and larch trees (Larix decidua Mill.)],

- coastal area (Benalmádena) - litter under cypress and pine trees.

The mites were extracted in Tullgren funnels, conserved and determined to species or genus, including the juvenile stages. In total, 5260 mites were investigated. The populations of oribatid species were characterized with the abundance $(A)$ and dominance $(D)$ indices, while the mite communities were compared with the Shannon index $H^{\prime}$ (ODum 1971), total abundance, and number of species. Names of oribatid species follow Subías (2004) and partly Weigmann (2006).

\section{RESULTS}

The investigated habitats of Andalusia were rather poor in soil oribatids in terms of abundance and species diversity. Their mean density was the highest in grassy patches in Granada, relatively high in cypress litter in Ronda and Granada, while in other habitats it was distinctly lower (Table 1). Most oribatid species lived in cypress litter in Ronda, while in other habitats the number of species was markedly lower. In these mite communities only several species were abundant, while others had a low density. For example, in the patches of grasses in Granada, high abundance and domi- 
Table 1. Mean abundance $\left(A=\right.$ individuals per $\left.500 \mathrm{~cm}^{3}\right)$ of all oribatid mites and individual species, dominance $(D=\%$ of total oribatid mites) indices of those species, and Shannon index of oribatid communities in some habitats of Andalusia. Species with maximum $D \leq 5$ are listed below the table. Cyp $=$ cypress litter; $\mathrm{Lar}=$ larch litter; $\mathrm{Pin}=$ pine litter; $\mathrm{Gra}=$ grasses; $\mathrm{Li}=$ mosses and lichens

\begin{tabular}{|c|c|c|c|c|c|c|c|c|c|c|}
\hline \multirow[t]{2}{*}{ Species } & \multicolumn{3}{|c|}{ Granada } & \multicolumn{5}{|c|}{ Ronda } & \multicolumn{2}{|c|}{ Benalmádena } \\
\hline & & Cyp & Pin & Gra & $\mathrm{Li}$ & Cyp & Pin & Lar & Cyp & Pin \\
\hline Mean abundance of Oribatida $(A)$ & & 164 & 21 & 330 & 3 & 275 & 74 & 81 & 48 & 40 \\
\hline Number of species & & 7 & 10 & 11 & 2 & 23 & 9 & 10 & 15 & 12 \\
\hline Shannon index $\left(H^{\prime}\right)$ & & 1.01 & 1.88 & 0.66 & 0.41 & 2.22 & 1.49 & 1.81 & 2.27 & 1.65 \\
\hline \multirow[t]{2}{*}{ Cosmochthonius lanatus (Michael, 1885) } & $A$ & 92 & 9 & 0 & 0 & 3 & 6 & 7 & $<1$ & 0 \\
\hline & $D$ & 56 & 25 & 0 & 0 & 1 & 8 & 9 & 1 & 0 \\
\hline \multirow{2}{*}{ Galumna sp. 1} & $A$ & 0 & 0 & 8 & 0 & 0 & 0 & 0 & 0 & 0 \\
\hline & $D$ & 0 & 0 & 2 & 0 & 0 & 0 & 0 & 0 & 0 \\
\hline \multirow{2}{*}{ Haplochthonius simplex (Willmann, 1930) } & $A$ & 57 & 2 & 22 & 0 & 3 & 2 & 8 & 6 & 10 \\
\hline & $D$ & 35 & 9 & 6 & 0 & 1 & 2 & 10 & 12 & 25 \\
\hline \multirow{2}{*}{$\begin{array}{l}\text { Nothrus anauniensis Canestrini et } \\
\text { Fanzago, } 1876\end{array}$} & $A$ & 0 & 0 & 0 & 0 & 14 & 0 & 0 & 0 & $<1$ \\
\hline & $D$ & 0 & 0 & 0 & 0 & 5 & 0 & 0 & 0 & 1 \\
\hline \multirow[t]{2}{*}{ Oribatula frisiae (Oudemans, 1916) } & $A$ & 4 & 2 & 280 & 0 & 3 & 2 & 1 & 6 & 3 \\
\hline & $D$ & 2 & 9 & 86 & 0 & 1 & 2 & 1 & 12 & 7 \\
\hline \multirow[t]{2}{*}{ O. guadarramica (Pérez-Ěńigo, 1978) } & $A$ & 0 & 1 & 9 & 0 & 0 & 0 & 0 & 0 & 0 \\
\hline & $D$ & 0 & 4 & 3 & 0 & 0 & 0 & 0 & 0 & 0 \\
\hline \multirow[t]{2}{*}{ O. tibialis (Nicolet, 1855) } & $A$ & 7 & 3 & 0 & 2 & 79 & 24 & 29 & 5 & 15 \\
\hline & $D$ & 4 & 13 & 0 & 86 & 29 & 32 & 36 & 10 & 37 \\
\hline \multirow[t]{2}{*}{ Phthiracarus sp. } & $A$ & 0 & 0 & 0 & 0 & 7 & 0 & 0 & 2 & $<1$ \\
\hline & $D$ & 0 & 0 & 0 & 0 & 3 & 0 & 0 & 4 & 1 \\
\hline \multirow[t]{2}{*}{ Pilogalumna crassiclava (Berlese, 1914) } & $A$ & 0 & 1 & 0 & 0 & 9 & 0 & 1 & 11 & $<1$ \\
\hline & $D$ & 0 & 4 & 0 & 0 & 3 & 0 & 1 & 23 & 1 \\
\hline \multirow[t]{2}{*}{ P. ornatula Grandjean, 1956} & $A$ & 0 & 0 & 0 & 0 & 0 & 0 & 0 & 4 & 0 \\
\hline & $D$ & 0 & 0 & 0 & 0 & 0 & 0 & 0 & 8 & 0 \\
\hline \multirow[t]{2}{*}{ Protoriobates sp. 1} & $A$ & 0 & 0 & 0 & 0 & 11 & 0 & 0 & 0 & 0 \\
\hline & $D$ & 0 & 0 & 0 & 0 & 4 & 0 & 0 & 0 & 0 \\
\hline \multirow[t]{2}{*}{ Ramusella clavipectinata (Michael, 1885) } & $A$ & 0 & 0 & 0 & 0 & 0 & 0 & 16 & 0 & 0 \\
\hline & $D$ & 0 & 0 & 0 & 0 & 0 & 0 & 20 & 0 & 0 \\
\hline \multirow[t]{2}{*}{ R. insculpta (Paoli, 1908) } & $A$ & 0 & 0 & 0 & 0 & 35 & 0 & 0 & 0 & 0 \\
\hline & $D$ & 0 & 0 & 0 & 0 & 13 & 0 & 0 & 0 & 0 \\
\hline \multirow[t]{2}{*}{ Scheloribates laevigatus (C. L. Koch, 1835) } & $A$ & 3 & 2 & 0 & 0 & 62 & 29 & 13 & 0 & 7 \\
\hline & $D$ & 2 & 9 & 0 & 0 & 22 & 39 & 16 & 0 & 17 \\
\hline \multirow[t]{2}{*}{ Scutovertex perforatulus Mihelčič, 1958} & $A$ & 0 & 0 & 3 & 0 & 0 & 0 & 0 & 0 & $<1$ \\
\hline & $D$ & 0 & 0 & 1 & 0 & 0 & 0 & 0 & 0 & 1 \\
\hline \multirow[t]{2}{*}{ Tectocepheus minor Berlese, 1903} & $A$ & 0 & 0 & 0 & 0 & 14 & 0 & 0 & 0 & 0 \\
\hline & $D$ & 0 & 0 & 0 & 0 & 5 & 0 & 0 & 0 & 0 \\
\hline \multirow[t]{2}{*}{ T. velatus (Michael, 1880) } & $A$ & 0 & 0 & 4 & 1 & 13 & 10 & 3 & 2 & 3 \\
\hline & $D$ & 0 & 0 & 1 & 14 & 5 & 13 & 4 & 4 & 7 \\
\hline
\end{tabular}


Granada, cypress litter: Damaeidae juv.; Eupelops juv.

Granada, pine litter: Adrodamaeus hispanicus (Grandjean, 1928); Eupelops juv.; Liacarus splendens (Coggi, 1898).

Granada, grass litter: Acrogalumna longipluma (Berlese, 1904); Adrodamaeus hispanicus; Hemileius initialis (Berlese, 1908); Oppiella nova (Oudemans, 1902); Passalozetes hispanicus Mihelčič, 1955.

Ronda, cypress litter: Acrogalumna longipluma; Amerobelba decedens (Berlese, 1908); Camisia segnis Hermann, 1804; Foseremaeus laciniatus (Berlese, 1905); Heminothrus peltifer (C. L. Koch, 1839); Liacarus splendens; Liochthonius sp.; Paralopheremaeus hispanicus (Ruitz, Kawash et Subias, 1990), Ramusella fasciata (Paoli, 1908), Suctobelba sp., Trichoribates sp.

Ronda, pine litter: Acritritia duplicata; Liacarus splendens; Suctobelba sp.

Ronda, larch litter: Acritritia duplicata; Liacarus splendens; Suctobelba sp.

Benalmádena, cypress litter: Acritritia duplicata (Grandjean, 1953); Belba sp.; Gratoppia italica (Bernini, 1973); Oppiella nova; Oribatula sp.1; Sphaerochthonius splendidus (Berlese, 1904); Suctobelba sp.

Benalmádena, pine litter: Acritritia duplicata; Adrodamaeus hispanicus; Liacarus splendens.

nance index were achieved by Oribatula frisiae (Oudemans, 1916), while in cypress litter relatively abundant were $O$. tibialis (Nicolet, 1855), Haplochthonius simplex (Willmann, 1930) and Scheloribates laevigatus (C. L. Koch, 1835). Consequently, the Shannon index for these mite communities was rather low, achieving higher values in cypress litter in Benalmádena and Ronda, and low values in patches of grasses or mosses and lichens in Granada.

Summer communities of oribatid mites were usually composed of adults. Juveniles dominated only in patches of grasses in Granada, mainly due to $O$. frisiae, whose juveniles were 13 times more numerous than adults (Table 2). Also H. simplex

Table 2. Age structure of oribatid species in some habitats of Andalusia. Juv = juvenile stages; Ad = adults

\begin{tabular}{|c|c|c|c|c|}
\hline Species & Habitat & Juv & Ad & Total \\
\hline Cosmochthonius lanatus & Granada, cypress litter & 27 & 65 & 92 \\
\hline \multirow[t]{2}{*}{ Haplochthonius simplex } & Granada, cypress litter & 38 & 19 & 57 \\
\hline & Granada, grasses & 10 & 12 & 22 \\
\hline Nothrus anauniensis & Ronda, cypress litter & 11 & 3 & 14 \\
\hline Oribatula frisiae & Granada, grasses & 260 & 20 & 280 \\
\hline \multirow[t]{3}{*}{ O. tibialis } & Ronda, cypress litter & 48 & 31 & 79 \\
\hline & Ronda, larch litter & 3 & 26 & 29 \\
\hline & Ronda, pine litter & 2 & 22 & 24 \\
\hline \multirow[t]{2}{*}{ Pilogalumna crassiclava } & Benalmádena, cypress litter & 1 & 10 & 11 \\
\hline & Ronda, cypress litter & 7 & 2 & 9 \\
\hline \multirow[t]{2}{*}{ Scheloribates laevigatus } & Ronda, cypress litter & 16 & 46 & 62 \\
\hline & Ronda, pine litter & 1 & 28 & 29 \\
\hline Tectocepheus velatus & Ronda, pine litter & 10 & 3 & 13 \\
\hline
\end{tabular}


was rich in juveniles in cypress litter in Granada, and O. tibialis and Nothrus anauniensis Canestrini et Fanzago, 1876 in cypress litter in Ronda. In contrast, in larch and pine litter in Ronda the population of $O$. tibialis comprised mainly adults. The age structure of $S$. laevigatus in Ronda depended greatly on the kind of litter: pine litter was rich in juveniles, while cypress litter was not.

\section{DISCUSSION}

Low densities of summer populations of oribatid mites in the investigated habitats of Andalusia seem to be typical for the Mediterranean region, and are probably due to the hot and dry summer, which is unfavorable for soil animals (ATTENBOROUGH et al. 1989). Thus these mites find better living conditions and multiply there in winter (Stamou \& SGardelis 1989). For the same reason, in the mountains (with lower temperature and higher precipitation), the density of oribatid mites was generally higher than in the costal area. The density of mites in cypress litter on Rhodes Island (Rhodes City Park and Filerimos Mt.) in Greece was also higher (SENICZAK \& SeNICZAK 2006) than in cypress litter in Ronda and Granada, similarly as in the patches of plants (grasses, mosses and lichens) of Crimean steppe, with a fresh sea breeze, where oribatid mites were more abundant (90-824 individuals per $\left.500 \mathrm{~cm}^{3}\right)$, richer in species (18-36 species), and their Shannon index of diversity was higher (SENICZAK et al. 2009) than in the studied habitats of Andalusia.

SuBíAs at al. (1985) investigated the density and species number of oribatid mites in Mediterranean fallow land near Madrid, and obtained comparable results. In October those authors noted the highest density of mites in thyme scrub litter, and slightly lower in grasses mixed with mosses and herbs, and in the soil under thyme scrub. In these habitats, 15-18 species of Oribatida were found, and the densities were comparable with that observed in cypress litter in Ronda. In scrub thyme litter and in the soil under it, Spherochthonius splendidus (Berlese, 1904) dominated, and Oribatula exarata and Passalozetes africanus Grandjean, 1932 were quite abundant. The latter 2 species also dominated in several investigated cropland habitats (SuBíAs at al. 1986), where the number of species was low (8-18 species).

In the investigated habitats of Andalusia, some species - like O. frisiae, O. tibialis and $H$. simplex - were rich in juveniles, which suggests that these species are well adapted to the hot and dry summer. Juveniles were also numerous in $O$. cognata and H. simplex on Rhodes Island (SENICZAK \& SENICZAK 2006). The former species inhabited cypress litter in Rhodes City Park and oak litter on Filerimos Mt., while the latter was found in bush litter on Louka Mt. A high participation of juveniles in oribatid mites is good for soil fertility, because they decompose the organic matter more actively than adults do (BERTHET 1963). This is partly due to the rich microflora of their alimentary canals, which is able to digest decay-proof substances, such as cellulose, lignin, and chitin (StefaniaK \& SEniczaK 1976). The juvenile stages have a thin cuticle and are attractive to predators, which activate soil life. 


\section{CONCLUSIONS}

1. The summer communities of oribatid mites in the investigated habitats of Andalusia were rather poor in terms of abundance and species diversity. Only several species achieved a higher density, so the Shannon index of these mite communities was rather low.

2. Based on cypress litter, the density of mites in the mountains (Granada, Ronda) was distinctly higher than in the coastal area (Benalmádena), which was probably caused by climatic conditions.

3. The Oribatida achieved the highest density in grassy patches in Granada, but most species occurred in cypress litter in Ronda.

4. Some species of Oribatida were rich in juveniles, but the age structure of species greatly depended on the kind of litter.

Acknowledgements: We sincerely thank Arguitxu de la Riva Caballero, MSc, who is a PhD student at the Department of Entomology, Bergen Museum, for supporting us with some Spanish references.

\section{REFERENCES}

Attenborough D., Whitfield P., Moore P. D., Cox B. 1989. The atlas of the living world. Marshal Edition Ltd., London.

Berthet P. 1963. Mesure de la consummation d'oxygene des Oribates (Acariens) de la litiere des foręts [Measurement of oxygen consummation of Oribatida (Acari) of forest litter]. In: Soil organisms (Doeksen J., Drift J. V. D., Eds), pp. 18-31, North Holland Publ., Amsterdam.

Norton R. A., Behan-Pelletier V. M. 2009. Suborder Oribatida. In: A manual of Acarology (Krantz G. W., Walter, D. E., Eds), pp. 430-564, Texas Tech Univ. Press, Lubbock.

Odum E. P. 1971. Fundaments of ecology. W. B. Saunders Co., Georgia.

Seniczak S., Kaczmarek S., Seniczak A. 2009. The oribatid mites (Acari, Oribatida) of some steppe habitats of Peninsula Tarhankut (Crimea, Ukraine). Biological Lett. 46: 97-103.

Seniczak S., Seniczak A. 2006. The oribatid mites (Acari) of some habitats of Rhodes Island (Greece). Biological Lett. 43(2): 215-219.

Stamou G. P., SGardelis S. P. 1989. Seasonal distribution patterns of oribatid mites (Acari: Cryptostigmata) in a forest ecosystem. J. Anim. Ecol. 58: 893-904.

Stefaniak O., Seniczak S. 1976. The microflora of the alimentary canal of Achipteria coleoptrata (Acarina, Oribatei). Pedobiologia 16: 185-194.

Subías L. S. 2004. Listado sistemático, sinonímico y biogeográfico de los Ácaros Oribátidos (Acariformes, Oribatida) del mundo (1758-2002) [Systematic, synonymic and biogeographical check - list of the world's oribatid mites (Acariformes, Oribatida) (1758-2002)]. Graellsia, 60: 3-305.

Subías L. S., Ruiz E., Minguez M. E. 1985. Aportación al conocimiento de las comunidades de Oribatidos (Acari) del erial mediterráneo [Contribution to the knowledge of the communities of Oribatida (Acari) from the Mediterranean heath]. Actas do II Congresso Ibérico de Ent., 1: 389-398.

Subías L. S., Ruiz E., Minguez M. E. 1986. Considerationes generals sobre la sucesión y bioindicación en los oribatidos (Acari, Oribatida) de un erial de cultivo mediterráneo [Consideration generals on the succession and bioindication of Oribatida (Acari, Oribatida) from a Mediterranean culture wasteland]. Actas de las VIII Journals, Sevilla, 121-131. 
Weigmann G. 2006. Hornmilben (Oribatida) [Oribatid mites (Oribatida)]. In: Die Tierwelt Deutschland und der angrenzenden Meeresteile. 76. Teil (DaHL F., Ed), pp. 1-520, Goecke \& Evers, Keltern. 